\title{
Strategic Digital Campaign to Improve Rural Health Workers Recruitment Process in Indonesia: A Case Study of Pencerah Nusantara Batch VI
}

\author{
Mochammad Fadjar Wibowo ${ }^{1}$, Yenuarizki² and Aghnia Jolanda Putri ${ }^{3}$ \\ Center for Indonesia's Study Development Initiative - (CISDI)
}

\begin{abstract}
With current geographical disparities, Indonesia's ratio of general practitioners (GPs) to population is still lower than the WHO-recommended figure. The Center for Indonesia's Strategic Initiatives (CISDI) initiated Pencerah Nusantara (PN), a team-based young health workers deployment program to rural areas to improve the distribution of human resources for health including GPs, nurses, midwives, public health specialists and health advocates. Entering PN's sixth year of implementation, aimed to attract more application from young health workers, particularly of GPs, CISDI employed strategic digital campaign involving strategic content development, strategic content channeling and strategic content promotion; as an intervention to improve the recruitment process of $\mathrm{PN}$ Batch 6 . This paper investigates whether the intervention manage to improve the recruitment process of $\mathrm{PN}$ and mainly usingsecondary data such as "Relative VolumeSearch" measuring Googlesearch popularity, social media insights measuring social media engagement and Google Analytics of PN weblog measuring weblog visits and online recruitment data measuring PN daily application rate from 2016 and 2017. Following the intervention, Google search popularity was doubled, social media engagement showed improvement range from 153 percent to 1,813 percent and PN daily application rate increased 148 percent of health workers and 192 percent of GP, compare to 32 percent and 44 percent of 2016 accordingly. A specifically targeted digital campaign implemented substantially improved recruitment promotion indicated by significant growth of PN daily application rate.
\end{abstract}

Keywords: digital marketing for development, digital campaign for human resources for health recruitment, human resources for health management

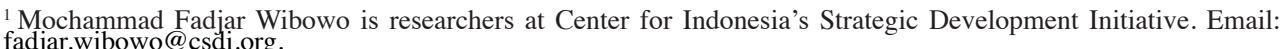
fadjar.wibowo@csdi.org.

${ }^{2}$ Yenuarizki is researchers at Center for Indonesia's Strategic Development Initiative.

${ }^{3}$ Aghnia Jolanda Putri is researchers at Center for Indonesia's Strategic Development Initiative.
} 


\section{Strategic Digital Campaign to Improve Rural Health Workers \\ Recruitment Process in Indonesia: A Case Study of Pencerah Nusantara Batch VI}

Mochammad Fadjar Wibowo, Yenuarizki, Aghnia Jolanda Putri

\section{Introduction}

\subsection{Background of Problems}

\subsubsection{Indonesia's health system performance and human resource for health distribution}

A well-functioning health system must have three principle inputs: human resources, physical capital and consumables. Within human resources for health framework, several issues that are frequently discussed in academic studies as being of the greatest relevance include the size, composition and distribution of the workforce, workforce training issues, the migration of health workers, the level of economic development and sociodemographic, geographical and cultural factors.

In the last two decades, the availability of human resources for health has grown and health worker-to-population ratios have increased in Indonesia. However, the 2010 target ratio of health personnel per 100,000 populations was not achieved. According to a report published by the Board of Development and Empowerment on Human Resources for Health, Indonesia falls short of human resource for health across all professional categories, with highest shortage rate in underdeveloped, borders, and islands regions (DTPK), which presented in Table 1.

In 2010, the Ministry of Health developed the Indonesia Human Resources for Health Development Plan Year 2011-2025, a long-term plan aimed to provide a comprehensive direction and reference for all stakeholders in the development of Human Resources for Health. The plan covers 13 categories of the health workforce i.e. medical specialist, general practitioner (GP), dentist, nurse, midwife, dental nurse, pharmacist, pharmaceutical assistant, sanitarian, nutritionist, public health practitioner, physiotherapist and medical technician.

The development of a platform for human resource for health distribution in Indonesia, including to rural areas, started when the government issued the Act No. 9 of 1960 about Health Basic Principles. The law obliges the central government to be fully responsible to the distribution of health workers throughout the country. Later, a Presidential Instruction No. 5 of 1974 was in place to enact the implementation of Bachelor Graduates Compulsory Work, popularly known as Wajib Kerja Sarjana. At the time, as central government civil servants, all health workers especially GPs, dentists, nurses, midwives, sanitarians and nutritionists were deployed to deprived areas 
for a fixed period of time, ranging from 2 to 5 years, depending on the area's degree of difficulties.

Table 1. Health workers availability and shortage at primary healthcare level

\begin{tabular}{|l|l|l|l|l|}
\hline $\begin{array}{l}\text { Human } \\
\text { resources }\end{array}$ & $\begin{array}{l}\text { Nationwide } \\
\text { availability }\end{array}$ & $\begin{array}{l}\text { Nationwide } \\
\text { shortage }\end{array}$ & availability & shortage \\
\hline $\begin{array}{l}\text { 1. General } \\
\text { practitioners }\end{array}$ & 14,840 & 149 & 130 & 64 \\
\hline 2. Dentists & 6,125 & 2,093 & 42 & 59 \\
\hline 3. Nurses & 78,675 & $\mathrm{~N} / \mathrm{A}$ & 95 & $\mathrm{~N} / \mathrm{A}$ \\
\hline $\begin{array}{l}\text { 4. Dental } \\
\text { nurses }\end{array}$ & 7,704 & 280 & 53 & 48 \\
\hline 5. Midwives & 83,000 & 21,797 & 496 & $\mathrm{~N} / \mathrm{A}$ \\
\hline 6. Pharmacists & 6,351 & $\mathrm{~N} / \mathrm{A}$ & $\mathrm{N} / \mathrm{A}$ & $\mathrm{N} / \mathrm{A}$ \\
\hline $\begin{array}{l}\text { 7. Pharmacist } \\
\text { assistants }\end{array}$ & 8,601 & 5,545 & 60 & 35 \\
\hline $\begin{array}{l}\text { 8. Public } \\
\text { health practi- } \\
\text { tioners }\end{array}$ & 1,356 & 13,019 & 54 & 249 \\
\hline 9. Sanitarians & 6,031 & 472 & 76 & 25 \\
\hline 10. Nutritionist & 7,547 & 303 & 67 & 34 \\
\hline $\begin{array}{l}\text { 11. Medical } \\
\text { technicians }\end{array}$ & 2,609 & 5,771 & 54 & 47 \\
\hline
\end{tabular}

Source: Board of Development and Empowerment on Human Resources for Health (BDEHRH), 2010

Entering the decentralization era in 2003, a number of multisectoral reforms to different aspects of the health system including the introduction of the Act Number 13 of 2003 on Manpower which revoked the Act Number 8 of 1961 on Bachelor Graduates Compulsory Work (WKS) were introduced. The Minister of Health then stipulated Regulation of 1540/Menkes/Per/XII/2002 on the Placement of Medical Personnel within Assigned Period of Service, casually known as contracted staff or PTT. This policy shifted the game rule of health workers assignment, especially GPs and dentists, from an obligatory to optional appointment. Hence, fewer GPs and dentists enrolled PTT and resulted in shortage in DTPK.

In the era of universal health coverage where the government aims to expand the National Health Insurance (JKN) coverage while improving quality of service, the issue of inequitable human health resources distribution, especially in rural areas, has continued to contribute to the low quality of health services. In regional and local level, the progressive introduction of local governments greater autonomy in the management of public service organizations, including primary health centres, has also impacted on health worker distribution. However, most of local administration still incapable of adequately managing human resources for health. 


\subsubsection{Pencerah Nusantara as an initiative on human resource for health distribution and its challenge in recruiting young health workers}

Between 2012 and 2015, under the management of the Office of Special Envoy of the President of the Republic of Indonesia on the Millennium Development Goals (OSE-MDG), a team-based health professionals deployment program called Pencerah Nusantara $(\mathrm{PN})$ was introduced to revitalize primary healthcare centres and its community-based health centres across seven areas with health problems $(D B K)$ in Indonesia. In period of three years, each of areas received three waves of Pencerah Nusantara teams. Following the transformation of OSE-MDG to CISDI in 2015, Pencerah Nusantara program continued to serving its second cohort in 9 areas of intervention within period of 2016 to 2019.

After the third year of PN implementation, the program has significantly improved primary health care center management and benefited 120,000 community members in seven deployment locations. In 2015 the initiative was scaled up and adapted by the Indonesian Ministry of Health as a nation-wide program known as Nusantara Sehat and run under Regulation of 16/Menkes/Per/2017 on the Special Assignment of Health Workers in Supporting Nusantara Sehat (NS) Program. While PN serves areas with health problems (DBK), NS deploying teams to DTPK.

Since its establishment, other than promoting human resource for health distribution, $\mathrm{PN}$ has been expected therefore publicised to become a platform for young professionals, with a maximum age of 30, and a background in medicine, public health, community empowerment and social sciences background to take part in national development. Due to their obvious and important differences, it is imperative that human capital for health is managed very differently from physical capital. As the program emphasised the implementation of interprofessional collaboration and multi-sectoral partnership approach, the young professionals recruited to $\mathrm{PN}$ teams are competitively selected and rigorously trained to be able to develop the capacity of local health providers and engage key stakeholders.

Along its five year of implementation, CISDI learned that reaching out and attracting young GPs to apply to the program as the main challenge in PN recruitment process. The promotion of PN human resources open recruitment were conducted though sending letters to the provincial offices of Indonesian Medical Association across 34 provinces, district health offices (DHO) in area of PN intervention, various universities with faculty of medicine and public health school and district development agency. Yet, this resulted in low talent engagement.

Considering the nature of communication and relation of such organization 
with young health workers, it is challenging to rely on them to reach the potential applicants. However, the challenge of meeting the increasing demand for sufficient supply of health professionals in times of existing and projected healthworkforce shortages is not only applied to the case of PN. Globally, 84 percent of human resources professionals in health sectors experience difficulty in recruiting candidates for full-time positions. The low number of applicants causes more than half of the cases and calls for outreach ignition. Thereupon, social media platforms become one of the selected means to congregate the recruitment of health workers.

To reach out and attract potential applicants, since Batch I PN, open recruitment announcement has also been promoted through social media, predominantly through Twitter. Despite Facebook has also been employed since the promotion of the first cohort, while Instagram was activated during the recruitment of Batch 4 PN or in the mid of 2015, engagement activity at both platforms were not optimised.

As shown by Cohort 1 column at Table 2, despite steady application growth from Batch I to Batch III, incoming applications from GP's continued to decrease. Entering the second Cohort, despite contrast growth of incoming applications from other categories, applications from GPs remained low and account only for 15 in Batch IV and 21 in Batch V. 
Table 2. Health workers applying to and recruited onto Pencerah Nusantara program

\begin{tabular}{|c|c|c|c|c|c|c|c|c|c|c|c|c|}
\hline \multicolumn{2}{|c|}{ Professional } & \multicolumn{5}{|c|}{ Cohort 1} & \multicolumn{6}{|c|}{ Cohort 2} \\
\hline & $\begin{array}{l}\text { Batch } \\
2012\end{array}$ & I. & $\begin{array}{l}\text { Batch } \\
2012\end{array}$ & II. & $\begin{array}{l}\text { Batch } \\
2012\end{array}$ & III. & $\begin{array}{l}\text { Batch } \\
2012\end{array}$ & IV. & $\begin{array}{l}\text { Batch } \\
2012\end{array}$ & V. & $\begin{array}{l}\text { Batch } \\
2012\end{array}$ & VI. \\
\hline $\begin{array}{l}\frac{7}{0} \\
\text { Oे } \\
\frac{\Phi}{\pi} \\
0\end{array}$ & $\frac{\overline{0}}{\frac{0}{0}}$ & 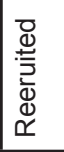 & $\frac{\frac{\overline{0}}{0}}{\frac{0}{0}}$ & 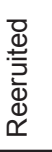 & $\frac{\frac{8}{0}}{\frac{0}{0}}$ & 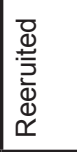 & $\begin{array}{l}\frac{\overline{0}}{\frac{0}{0}} \\
\frac{0}{2} \\
\frac{0}{4}\end{array}$ & 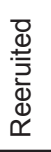 & $\frac{\frac{\overline{0}}{\overline{0}}}{\frac{0}{2}}$ & 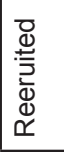 & $\frac{\frac{0}{0}}{\frac{0}{0}}$ & 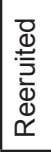 \\
\hline 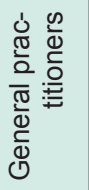 & 45 & 8 & 15 & 7 & 11 & 7 & 15 & 9 & 21 & 9 & 40 & 5 \\
\hline 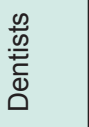 & 6 & 0 & 4 & 0 & 3 & 0 & 5 & 2 & 23 & 5 & 7 & 0 \\
\hline 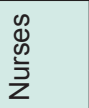 & 29 & 8 & 36 & 7 & 51 & 8 & 464 & 9 & 549 & 9 & 825 & 3 \\
\hline 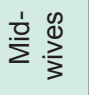 & 22 & 6 & 73 & 6 & 145 & 7 & 941 & 9 & 1007 & 9 & 1630 & 7 \\
\hline 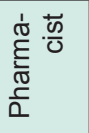 & 9 & 2 & 16 & 1 & 2 & 0 & 64 & 1 & 130 & 0 & 217 & 0 \\
\hline 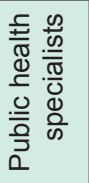 & 30 & 5 & 31 & 8 & 33 & N/A & 555 & 8 & 591 & 13 & 1122 & 7 \\
\hline 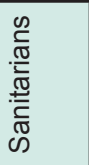 & 3 & 0 & 7 & 0 & 6 & N/A & 167 & 1 & 166 & 0 & 234 & 0 \\
\hline 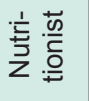 & 15 & 2 & 17 & 4 & 9 & $\mathrm{~N} / \mathrm{A}$ & 177 & 4 & 248 & 3 & 340 & 4 \\
\hline 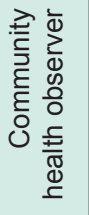 & 28 & 1 & 31 & 2 & 95 & 13 & 131 & 4 & 366 & 2 & 634 & 0 \\
\hline $\begin{array}{l}\overline{\widetilde{\pi}} \\
\stackrel{0}{0}\end{array}$ & 187 & 32 & 230 & 35 & 355 & 35 & 2429 & 47 & 3101 & 50 & 5049 & 26 \\
\hline
\end{tabular}

Source: Information and Communication Technology Division, Center for Indonesia's Strategic Development Initiatives (CISDI), 2017 


\subsubsection{Digital marketing campaign as innovative approach in talent recruitment}

With the evolution of electronic media, internet could link millions of people at the same time. The internet is characterised as facilitating communication, information sharing, interoperability, user-centered design and collaboration on the World Wide Web. As of 2018, four billion people worldwide are connected to the internet and three billion of them are active on social media. With 258 inhabitants, 132 billion Indonesians have enjoyed and active on the internet.

Figure 1 Top 10 Social Media in Indonesia in 2018

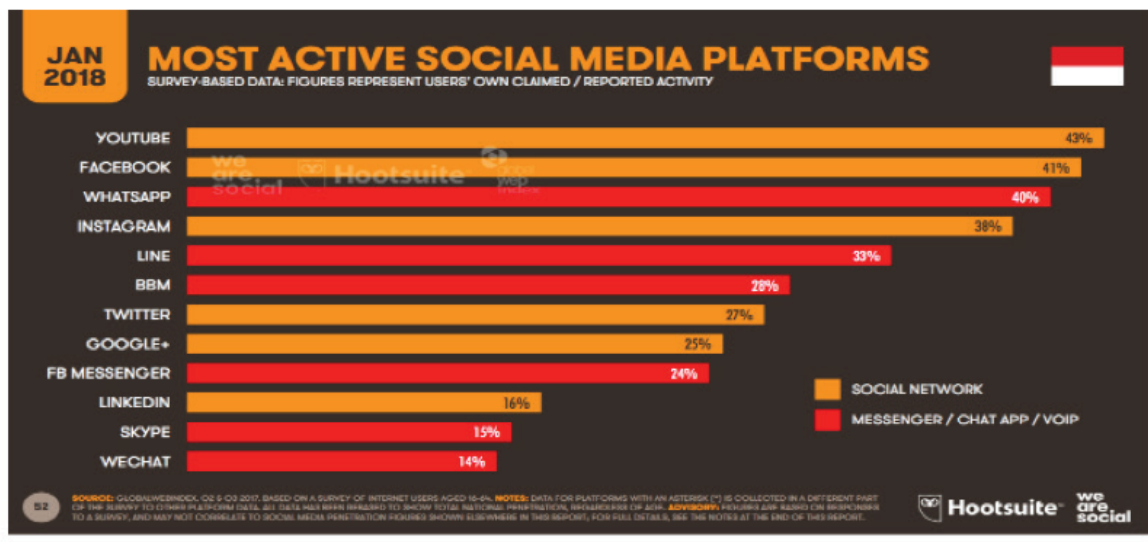

Source: WeAreSocial. Report. June 22, 2018. https://digitalreport.wearsocial.com

Over the past decade, the popularity of social web-based applications has risen whose central operation is based on user-generated content, connecting a profile with those of other individuals and/or groups. With the rise in social networks, individuals can easily share experiences and information with other users including in the area of public health. Social media engagement is social - it is participatory and reciprocal, lending itself to conversations and interactions between and among a public health organization and its diverse audiences via social media channels.

The rising usage of social media can be benefited for different things including for seeking work. Among job seekers, a LinkedIn profile is perceived as the most important of social media channels, with 85 percent of survey respondents holding membership of this site. Facebook and Twitter were cited as the second (74\%) and third (39\%) most popular options. Instagram follow suits with 38 percent and Google with 19 percent. Whereas, Indonesians use Facebook and Instagram most. 


\subsubsection{Strategic digital campaign application to improve Pencerah Nusantara human resource for health recruitment}

The nature of medical work that often inquire frequent mobility contributes to the challenges of effective recruitment promotion, especially to GPs. Therefore, measures to reach them should suit the nature of their employment and job-seeking attitude. Given the situation, social media with its social listening capacity pose potentials to reach out health workers, including GP's better.

Social listening enables brands and organizations to identify and assess public opinion towards them. Search engines like Google stores information users have searched, and provide data to support advertising agencies, small businesses, corporations, and researchers among others and measured by the relative volume search (RVS). Learning Google-based information seeking behaviour helps one to understand the public attitude, including interests and thus helps to distribute advertisements based on the most searched keywords. Google Trend analysis extracted on "Pencerah Nusantara" keywords between January 1st 2012 to December 31st 2016 indicated that the keyword has far lower RVS compared to those of programs of its kind, "Indonesia Mengajar" and "Nusantara Sehat".

Since the establishment of Nusantara Sehat and its promotion in 2015, the relative volume search (RVS) of "Nusantara Sehat" has rosen. Since "Nusantara Sehat" and "Pencerah Nusantara" keywords are recognised as inter-related by Google algorithm, "Nusantara Sehat" has escalated the relative volume search of "Pencerah Nusantara" starting from 2015, as Figure 2 captured. Entering the recruitment phase of Batch $6 \mathrm{PN}$ in the middle of 2017, human resource recruitment promotion which is indicated by improved daily application rate, was to be improved especially through improving its digital campaign.

Figure 2. "Pencerah Nusantara" keyword trend in comparison to "Nusantara Sehat" and "Indonesia Mengajar" in 2012-2016

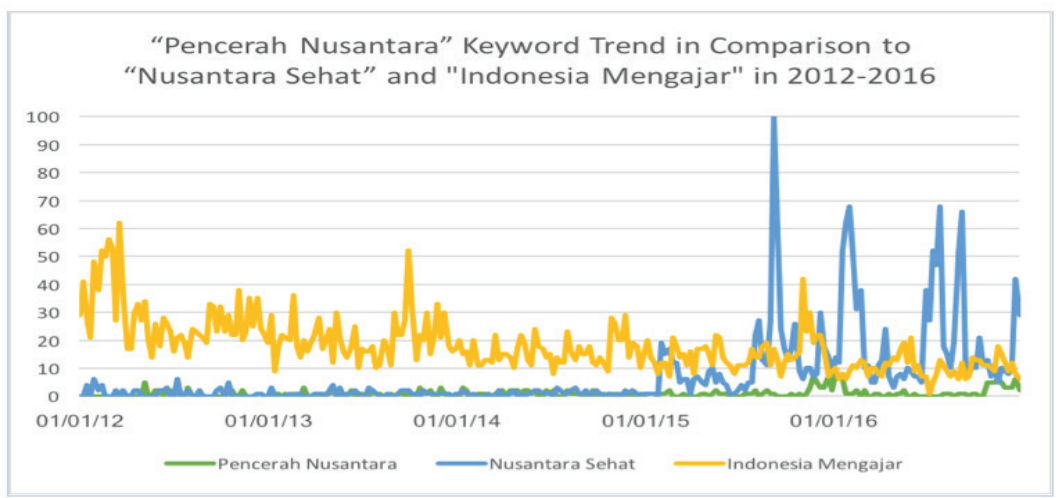

Source: extracted from https://trends.google.co.id. 


\subsection{The Problems}

Given the situation as explained above, CISDI then found out that social media and user-generated content have its own "influences" in digital platform. Authors then hereby came up to examine whether strategic digital campaign can improve the recruitment process of Pencerah Nusantara program, particularly its promotional aspect indicated by its daily application rate.

\subsection{Logical Framework}

In accordance to analyze the main problem of this research, writers come up with two relevant theories which will help writers to address the problem. The theories are: Laswell Communication Theory and Uses and Grantification Theory. According to Laswell, an act of communication by emphasizing who does the activity, what does it say, through which channel, to whom it conducts the activity, and with what effect (see Figure 3)

Figure 3. Harold Lasswell Communication Model

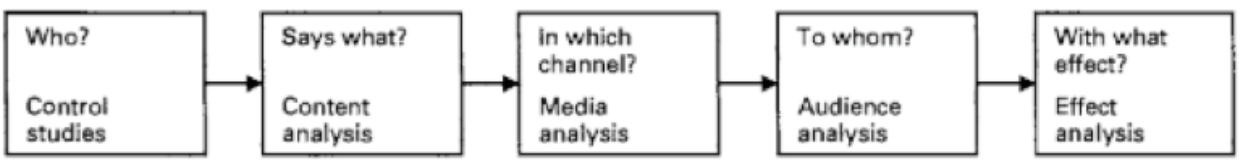

Although mass media communication possesses an aptitude as a central point of communication research, viewers, however, also possess their own preference. Uses and Gratifications Theory (UGT) posits a few basic assumptions:

- The audience takes an active role in selecting a medium, as well as interpreting it and integrating it into their lives.

- Different types of media compete against each other and against other sources of gratification for viewers' attention.

- The medium that provides the most satisfaction for a person will be used more often than other types.

Reflecting through UGT, CISDI understands that social media is the right platform to distribute information to the specifically targeted audience for PN recruitment. In correspond to the social media engagement reports, most of the social media accounts of PN are followed by people aged 18-24 years old. Nonetheless, the right information must be given if only CISDI conduct a research, with the help of Google Trend, on topics of interest of the targeted audience. Hence, digital marketing campaign is the most effective strategy to be implemented as it offers a wide outreach using its user-targeted content. 


\section{Literature Review}

On this writing, some theories and concepts, which are relevant with the topic discussed: digital marketing and social media engagement, were used. Obar and Wildman (2015) stated that user-generated content is the fuel of social media. Usergenerated content includes the action and decision which interlinkages us all in social media platform, for instance the profile connections to others in Facebook, the tweets posted in Twitter and the photos uploaded in Instagram. Then, Heldman, Schindelar, Weaver (2013) stated that social media is a platform in which relevant content can be shared within it, includes public health related content. Public health related content creator, can also engage readers through their content and collecting feedback from them as well. The reciprocal relationship enabled among content creators and readers potentially led the creation of new opportunities for the content creators' organization.

Jianqing, Xu and Whinston (2009) assumed that internet is a social sphere where people can easily exchange information and knowledge to each other which made them as "online community". Online communities are the actors of the new era of content creation by optimizing user-generated content as their platform. In addition, Littlejohn, Foss and Oetzel (2017) stated that the shifting of our daily life and needs along with the rise of internet and advanced technology created a new form of reality which commonly known today as "new media". This electronic media evolution could link millions of people at the same time.

According to Laswell (1948), an act of communication ideally would answer the questions of: Who, Says What, In Which Channel, To Whom, With What Effect. Then, Sapienza, Iyer and Veenstra (2015), quoted that the intent behind this is to ensure that it covers the gamut of possible interpretations of his construct of communication without referencing any one in particular. Meanwhile, Uses and Gratifications Theory used to understand why and how people seek specific media. Thomas E. Ruggiero (2000) argued that the internet is an applicable medium where the theory will be put on practice.

\section{Methods/Methodology}

\subsection{Paper Methodology}

This paper is written mainly using secondary data such as "Relative Volume Search" measuring "pencerah nusantara" Google search popularity, PN's social media engagement percentage and PN's weblog number of visit and online recruitment dataset. Data from 2016 and 2017 were then compared. 


\subsection{Study Case Methodology: Strategic Digital Campaign on Pencerah Nusantara}

\section{Recruitment Process}

\subsubsection{Pencerah Nusantara digital recruitment promotion content analysis}

CISDI employed a thorough content analysis employing Google Trend, social media analytics and media monitoring to understand the young health workers, as the target population, and their online information seeking behaviours as well as job-seeking attitude using search terms keywords related to "pencerah nusantara”. As Google suggested "nusantara sehat" was an interlinked keyword with "pencerah nusantara", it was then used as a proxy to learn about the information seeking behaviours of Google users, presumably health professionals, regarding their job-seeking attitude. Google Trend also provided personal information of users accessing the keyword including age, sex, and geographical location.

Separately, focusing on number of followers and engagement percentage, social media contents shared throughout 2016 were analysed quantitatively to identify contents with high engagement. Personal information of users accessing social media accounts of PN including age, sex, profession and interest were analysed. The analysis also suggested that each social media platform inquired specific strategic approach based on audience and functions and that the predominant target audience of $\mathrm{PN}$ are young health workers aged 18-34 years old, residing in urban areas of South Sulawesi, Aceh and Central Java.

\subsubsection{Development of Pencerah Nusantara strategic digital campaign planning}

Following combined analytical findings, as seen at Figure 4 and Figure 5, those using "pencerah nusantara" keyword as Google search term between January 1st 2017 to October 22nd were internet users accessing Google from provinces with high density of medical and health schools while geographic distribution data of PN weblog showed distribution of viewers in respected urban area.

Figure 4. Age distributions belong to those using "pencerah nusantara" keyword as Google search term between January 1, 2017 to October 20, 2017 (prior to the start of application window period)

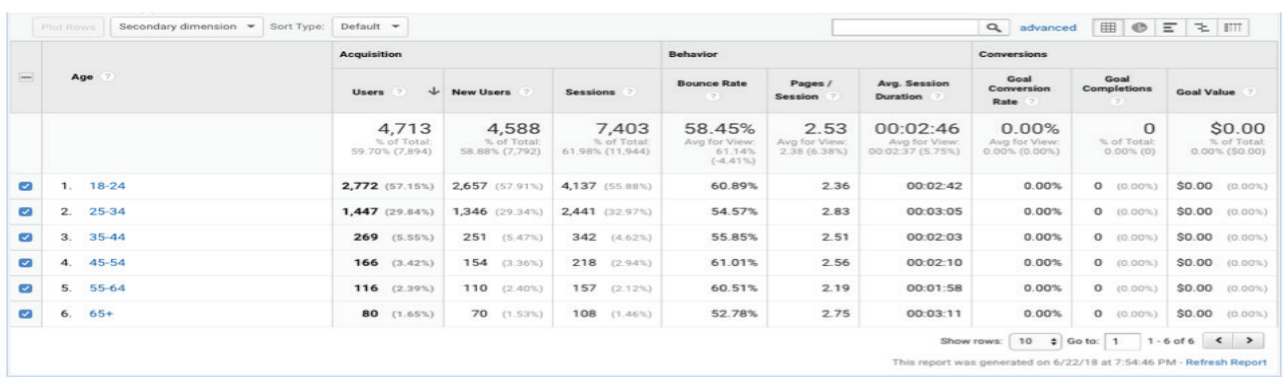


Figure 5. Geographical distributions belong to those using "pencerah nusantara" keyword as Google search term between January 1, 2017 to October 20, 2017 (prior to the start of application window period)

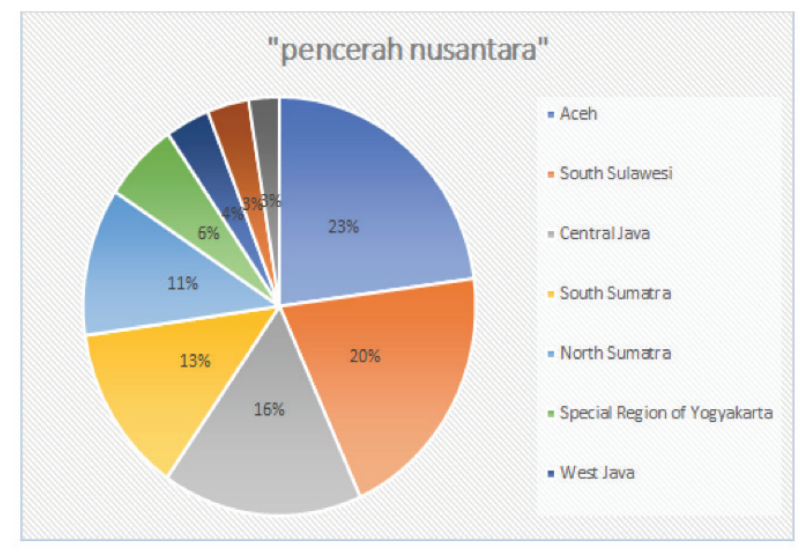

Audience charactheristics analysis showed that targeted audience segment were known to be internet users with following charactheristics: active or former students from health major, reside in urban cities, possess limited or no information about Pencerah Nusantara. Meanwhile, the most frequent search terms relevant to "pencerah nusantara" included salary, application process, requirements, and the selection process. All information were capitalised throughout all digital communication contents and channels with PN's weblog as the main information reference.

\subsubsection{Implementation of Pencerah Nusantara digital campaign strategy}

Considering the current engagement of PN target population and CISDI capacity in running social media; Facebook, Instagram, Twitter, and WhatsApp were chosen as platforms to apply strategic digital campaign of PN. Content production especially graphic visuals were intensified and posting activities through digital communications channels was made regular and partnership with online media to expand content outreach was established.

To ensure that all of the contents reach out the group of audiences that best suit the specifically targeted audience of $\mathrm{PN}$, a monthly monitored digital campaigns across all platforms was made sure to be well-connected with PN tailored content outreaching to targeted audience. To optimize the campaign, along with Search Engine Optimization (SEO) techniques, CISDI augmented social media outreach through applying advertisement on Facebook and Instagram.

To facilitate communication between the CISDI management and the potential applicant of PN who sought out further in-depth information or to 
reaffirm the information they have previously obtained, four WhatsApp discussions on PN open recruitment were conducted and attended by 397 participants.

\subsubsection{Monitoring \& evaluation of Pencerah Nusantara digital campaign}

Monitoring and evaluation design of digital campaigns varies across different types of digital marketing campaign and might employ qualitative and quantitative data analysis or both. PN digital campaign utilizes Google Trend analysis, social media insights and the Google Analytics that are extracted and analysed monthly.

Variables, commonly called as metrics in digital evaluation, to analyse in Google Trend Analysis including suggested phrases and its performance. In social media monitoring and evaluation, essential metrics to monitor and evaluate include number of followers, impressions, reach and engagement are generously provided despite merely for two retrospective years. As weblogs could easily be embedded with Google analytics, metrics to be cultivated including views and unique visitors.

To measure the overall improvement and success of the strategic digital campaign social media metrics within the application window period across 2016 and 2017 were extracted. Dataset of PN incoming application in 2015, 2016 and 2017 to examine the improvement of PN incoming applications for both GP and accumulative health professional. To objectively measure improvement, since every application window has different period length, data being examined were of daily rate of account registration, of general application and of GP applications.

\section{Results, Analysis, and Discussions}

\subsection{Result}

\subsubsection{Improvement of Pencerah Nusantara digital campaign and relative search volume of "pencerah nusantara"}

Following strategic digital campaign in 2017, digital metrics across all social media accounts, chat platform and weblog of PN and media coverage were increased as seen in Table 3. While media coverage decreased for 11\% in 2017. Digital visibility of "pencerah nusantara" improved as shown by Google Trend analysis of "pencerah nusantara" keywords between January 1st 2015 to December 31st 2017. At the end of the Figure 6, "pencerah nusantara" RVS line reached its highest amplitude and for the first time was higher than of "indonesia mengajar". This is aligned with the application period of PN Batch 6 which took place between October to December 2017. 
Table 3. Metrics summary of Pencerah Nusantara digital campaign in 2016 and 2017

\begin{tabular}{|c|c|c|c|}
\hline Social Media Type & 2016 & 2017 & Growth Rate \\
\hline \multicolumn{4}{|l|}{ Facebook } \\
\hline Post & 21 & 48 & $128 \%$ \\
\hline Followers & 5,473 & 9,000 & $64 \%$ \\
\hline Reach & 32,600 & 91,204 & $179 \%$ \\
\hline Engagement & 5,996 & 15,175 & $153 \%$ \\
\hline \multicolumn{4}{|l|}{ Instagram } \\
\hline Post & 277 & 309 & $11.5 \%$ \\
\hline Followers & 3,341 & 8,500 & $154 \%$ \\
\hline Profile Visit & $\mathrm{N} / \mathrm{A}$ & 1,778 & $\mathrm{~N} / \mathrm{A}$ \\
\hline Impressions & 202,213 & 603,564 & $198 \%$ \\
\hline Engagement & 608 & 11,632 & $1,813 \%$ \\
\hline \multicolumn{4}{|l|}{ Twitter } \\
\hline Post & 506 & 259 & $-48.8 \%$ \\
\hline Followers & 7,190 & 7,959 & $10.6 \%$ \\
\hline Profile Visit & 5,891 & 19,349 & $228.4 \%$ \\
\hline Impressions & 79,700 & 315,269 & $295.5 \%$ \\
\hline Engagement & 2,764 & 8,160 & $195.2 \%$ \\
\hline \multicolumn{4}{|l|}{ Pencerah Nusantara Web Blog } \\
\hline Post & 12 & 24 & $100 \%$ \\
\hline Views & 16,810 & 33,523 & $99.4 \%$ \\
\hline \multicolumn{4}{|l|}{ WhatsApp Discussion } \\
\hline Number of Sessions being Held & 3 & 4 & $33.3 \%$ \\
\hline Number of Participants & 117 & 397 & $239.3 \%$ \\
\hline \multicolumn{4}{|l|}{ Media Coverage } \\
\hline Covering Media & 44 & 39 & $-11.3 \%$ \\
\hline Covering News Articles & 135 & 120 & $-11.1 \%$ \\
\hline
\end{tabular}

Figure 6. "Pencerah Nusantara" Keyword Weekly Relative Search Volume Trends In Comparison To "Nusantara Sehat” And “Indonesia Mengajar” In 2015-2017

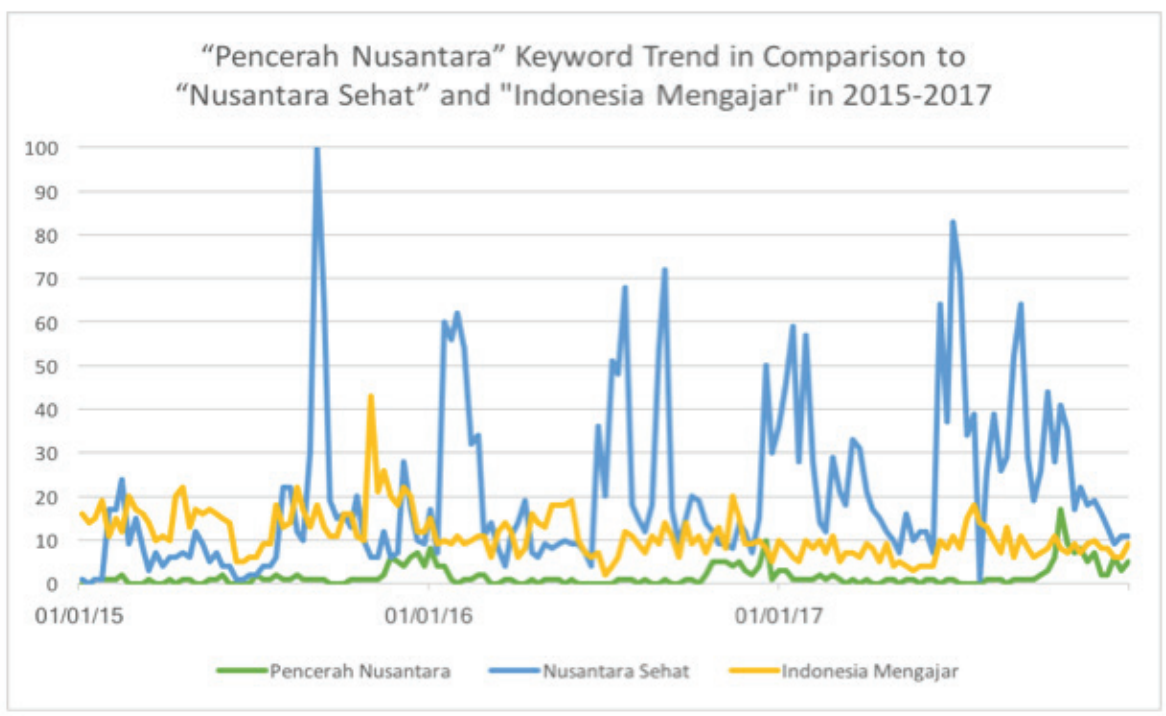

Source: extracted from https://trends.google.co.id. 


\subsubsection{Improvement of Pencerah Nusantara overall human resource for health and General Practitioners (GPs) incoming application}

On incoming application evaluation, there are significant improvement took place in 2017 across three indicators being measured, daily rate of account registration, general application and GP applications, as seen at Table 4 where we compare three different batches of PN. Growth percentages of these three daily rates in 2017 was the highest compared to 2016 when digital campaigns have not been strategically planned.

In 2017, the daily rate of application account registration rose $131 \%$ compared to $29 \%$ growth in 2016 . The daily rate of general application saw $148 \%$ growth from the previous year's 32\%, and the daily rate of GPs application increased 191.6\% from 44\% of the year before. With such improvement, the 2017 incoming applications of PN had the best performance despite of the shorter application period (only 38 days). When the growth of Google RVS trend throughout open recruitment period in 2015, 2016 and 2017 compared with the growth of daily application rate of PN of all health professionals and of GPs, the growing trend shows harmonious alignment as seen at Figure 7 and 8 .

Table 4. Pencerah Nusantara overall health workers and GP's incoming application

\begin{tabular}{|c|c|c|c|}
\hline $\begin{array}{c}\text { Pencerah Nusantara } \\
\text { Applicant }\end{array}$ & Batch IV, 2015 & Batch V, 2016 & Batch VI, 2017 \\
\hline $\begin{array}{c}\text { A. Application account } \\
\text { registration } \\
\text { (number of account regis- } \\
\text { tered) }\end{array}$ & 5,505 & 6,804 & 10,307 \\
\hline $\begin{array}{c}\text { B. General application } \\
\text { (number of registration com- } \\
\text { pleted) }\end{array}$ & 2,429 & 3,101 & 5,049 \\
\hline $\begin{array}{c}\text { C. Application from GP } \\
\text { (number of GPs completed } \\
\text { registration) }\end{array}$ & 15 & 21 & $271.2(131 \%)^{*}$ \\
\hline D. Application period (days) & 60 & $117.3(29 \%)^{*}$ & 38 \\
\hline $\begin{array}{c}\text { E. Daily application account } \\
\text { registration rate } \\
\text { (Total account registration / } \\
\text { Application period) }\end{array}$ & 91.75 & $53.46(32 \%)^{*}$ & $132.86(148 \%)^{*}$ \\
\hline $\begin{array}{c}\text { F. Daily general application } \\
\text { rate } \\
\text { (Total application / Application } \\
\text { period) }\end{array}$ & 40.49 & $0.36(44 \%)^{*}$ & $1.05(191.6 \%)^{*}$ \\
\hline $\begin{array}{c}\text { G. Daily GP's application } \\
\text { rate } \\
\text { (Applic ation from GP / Appli- } \\
\text { cation Period) }\end{array}$ & 0.25 & & 25 \\
\hline
\end{tabular}


Figure 7. Daily application rate of Pencerah Nusantara all Figure 8. Daily application rate of Pencerah Nusantara health professionals and Google RVS trend throughout from GP and Google RVS trend throughout open reopen recruitment period in 2015, 2016 and $2017 \quad$ cruitment period in 2015, 2016 and 2017
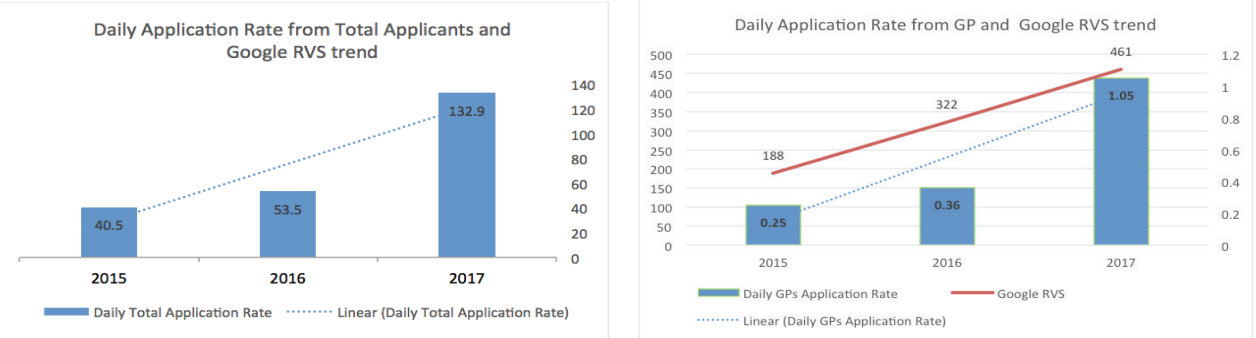

\subsection{Discussions}

Along with the improvement shown on the RVS of "pencerah nusantara" keyword, on metrics of our digital campaign and incoming applications of PN, it is arguable that CISDI has successfully developed a strategic digital campaign that address behaviours change. The result of strategic digital campaign were aligned with significant growth of branding awareness which was represented by digital visibility which was measured by the rise of RVS; and behaviours change among health professionals toward PN application represented by the significant growth of the incoming applications, including applications coming from GPs.

In Indonesia, where Google Search acquires 98.3\% search engine market, RSV algorithmic is arguably the most appropriate way to measure brand reputation in digital sphere. Employing Google Trends in generating hypotheses about public awareness and interest in multiple aspects of health and development work are therefore relevant considering today's healthcare talent information-seeking behaviours.

To strategically develop digital campaign, CISDI responded the analysis of Google Trends which mainly discussed topics on compensation, selection process and general requirement by only creating and disseminating digital contents that suited the analysis. To optimize the effect of the digital campaign, SEO technique was applied, and digital advertisement feature was activated.

After all, the use of digital metrics growth rate and incoming application growth rate to showcase the digital campaign driven incoming application improvement was of innovative approach that writers applied. Application of a more rigorous and academically proven means of verification to measure the correlation of digital campaign success and behaviours change is necessary to conduct in the future. 


\section{Conclusion and Recommendation}

This paper In our case study, strategic digital campaign aimed at engaging more application while growing PN brand popularity has resulted a significant increase in number of applications to the PN program. Understanding the specifically targeted audience is important to enable the development of appropriate digital campaign, both in determining type of potential messages and channel. Such effort could be done through strategic planning that takes the benefit of information provided by contemporary analytical tools that has the ability to provide insight on type of content, media, audience characteristics and potential effect.

To optimize the development and distribution of digital content, techniques like Search Engine Optimization (SEO) and Search Engine Marketing (SEM) could also be employed. A well-designed digital campaign results in an improved digital campaign metrics and the RVS of PN, could improve the incoming applications and therefore the outcome of health workers recruitment process. This approach is potential to raise public interest in exploring the study of digital data exploration from contemporary sources like Google and social media to encourage health and development campaign analysts to undertake better analysis based on marketing practices and therefore to improve digital campaign strategies.

\section{References}

Anderson, L. (2017). Using Social Listening Data to Monitor Misuse and Nonmedical Use of Bupropion: A Content Analysis. JMIR Public Health and Surveillance, 3(1): e6.

Badan Pusat Statistik. (2017). Statistical Yearbook of Indonesia 2017. Jakarta: Badan Pusat Statistik.

CISDI. 2014. Pencerah Nusantara. http://cisdi.org/pages/index/pencerah-nusantara

Heldman, A., Schindelar, J., \& Weaver, J. (2013). Social Media Engagement and Public Health Communication: Implications for Public Health Organizations Being Truly "Social". Public Health Reviews. 35:13.

Jianqing, C., Xu, H., \& Whinston, A. (2011). Moderated Online Communities and Quality of User-Generated Content. Journal of Management Information Systems 28, no. 2: 237-68.

Kabene, S., Orchard, C., Howard, J., Soriano, M., \& Leduc, R. (2006). The importance of human resources management in health care: a global context. Human Resources for Health, 4:20.

Kementerian Kesehatan Republik Indonesia. (2011). Rencana Pengembangan Tenaga Kesehatan Tahun 2011-2025. Jakarta: Kementerian Kesehatan Republik Indonesia. 
Littlejohn, S, W., K. Foss., \& J. G. Oetzel. (2017). Theories of Human Communication. IL: Waveland Press.

Mahendradhata, Y. (2017). The Republic of Indonesia Health System Review. Health Systems in Transition Vol 7 No. 1. India: WHO.

NN. Robert Walters Whitepaper: Using Social Media in the Recruitment Process. Retrieved from https://www.robertwalters.com/content/dam/ robert-walters/corporate/news-and-pr/files/whitepapers/using-social-media-in-the-recruitment-process.pdf

Obar, J., Wildman, S. (2015). Social Media Definition and the Governance Challenge: An Introduction to the Special Issue. Telecommunications Policy, 39(9), 745-750.

O’Reilly, T. (2006). Web 2.0 Compact Definition: Trying Again. O'Reilly Radar (blog). Retrieved June 22, 2018 from http://radar.oreilly.com/2006/12/ web-20-compact-definition-tryi.html..

Phillips-Wren, G., Doran, R., \& Merrill, K., (2016). Creating a value proposition with a social media strategy for talent acquisition. Journal of Decision Systems, 25:1, 450-462.

Pencerah Nusantara. 2012. Pencerah Nusantara. http://pencerahnusantara. org

Ruggiero, T. (2000). Uses and Gratifications Theory in the 21st Century. Mass Communication and Society 3, no. 1: 3-37.

Schein, R., Wilson, K., \& Keelan, J., (2010). Literature review on effectiveness of the use of social media [electronic resource]: a report for Peel Public Health. Canadian health research collection, no. 73: 27-31.

Statista. WhatsApp: Mobile Usage Penetration by Country. Statista. Retrieved June 22, 2018 from https://www.statista.com/statistics/291540/mobile-internet-user-whatsapp/\#0.

The Ministry of Health of the Republic of Indonesia. Special Assignment of Health Workers in Supporting Nusantara Sehat Program, PMK 16-2017 (Jakarta, 2017), Retrieved June 21, 2018, from http://hukor.depkes. go.id/uploads/produk hukum/PMK No. 16 ttg Nusantara Sehat. pdf

WeAreSocial. Report. Retrieved June 22, 2018 from https://digitalreport. wearesocial.com.

World Health Organization. (2000). World Health Report 2000, Health Systems: Improving Performance. Geneva: WHO. Retrieved from http:// www.who.int.proxy.lib.uwo.ca:2048/whr/2000/en/whr00 ch4 en.pdf 